due to the interference of three storms." Mr. Stevenson gives a number of instances of interfering cyclones which confirm this view. The points of interference, where two cyclones strike and revolve against each other, are best marked by a peculiarly and treacherously fine rain.

It may not inappropriately be added here that the cyclone theory; so strikingly illustrated by the hurricanes of the West Indies, has been demonstrated by Dove to apply to the typhoons of the Indian Ocean and China Seas. And Mr. Thorn has long since shown that the theory holds good for the storms of the Indian Ocean, scuth of the equator.

\section{EXHIBITION AT MOSCOW}

$T \mathrm{HE}$ Society of Arts has been exerting itself to ensure that England shall take part in the International Exhibition to take place at Moscow next year. At a recent meeting of the Council a deputation was received, consisting of M. Philip Koroleff, Conseiller d'Etat Actuel, Director of the Moscow Agricultural Academy and Preresident of the Educational Department of the Exhibition, MM, Lvoff, Nicholas Saenger, Secretary of the Society of Friends of Natural Science, and the Rev. Basil E. Popove.

M. Koroleff stated that on June II, I872, the Society of Friends of Natural Science, Anthropology, and Ethnography, attached to the Imperial University at Moscow, proposes, with the permission of his Imperial Majesty, to celebrate the 2ooth anniversary of the birth of Peter the Great, falling on that day, by the opening of a Polytechnic Exhibition in Moscow.

This exhibition, which is intended to form the foundation of a Central Polytechnic Museum in the old capital of Russia, and to present, as far as possible, a complete view of the present relations of Natural Science and Technicology to arts and commerce in Russia, as well as of the progress made by the Russian nation in applied sciences throughout a period of two centuries, since the time of Peter the Great, will, in the opinion of Russian naturalists, form a most suitable tribute to the genius of this great historical character, and communicate a more elevated and especially interesting feature to the festival in his honour.

This exhibition is not, strictly speaking, an international cne, for, in accordance with its immediate object, it is proposed to limit the number of nations represented in it. The co-operation of German, French, Belgian, and Dutch exhibitors is hoped for, but the desired sympathy and aid is more particularly requested from England, which has attained, in comparison with other nations, such vast and unsurpassed results in that particular sphere, comprising the applications of science to art and commerce, within the limits of which it is proposed to keep the exhibition.

The Applied Natural Sciences and Technicology will form the two great divisions in the exhibition. It is in these two branches of social life that England has given so great an impulse to its own people, and is able to do the same in the case of other nations.

The exhibition is not a commercial undertaking. Its idea has been started, and is being carried out, by men devoted to science and art, who have accordingly based it, not on the principle of competition, but on that of previous invitation, and selection by competent judges.

In view of the proposed formation of a Polytechnic Muscum in Moscow, the Committee will also lake the necessary measures that articles considered essential to form parts of a systematic collection in it, should be, if possible, secured for the museum.

\section{SOLAR RADIATION TEMPERATURES} N. NATure of August 24th, page 325 , you quote the
sun and shade temperatures published by Mr. $H$. Steward and Mr.F. Nunes, of Chiselhurst, and conclude with the following sentence-"Surely there must be an error somewhere. The maximum temperature of $\mathrm{Mr}$. S. or Mr. N. differ by $40^{\circ}$ and $50^{\circ}$ ! Who is to teach or correct amateur meteorologists?" With your permission $I$ will endeavour (I) to explain the possible cause of these discrepancies, (2) to show that it is to "amateur meteorologists" alone that we are indebted for $(\alpha)$ all published information on the subject, and $(\beta)$ for the inauguration of a system of strictly comparable observations on the temperature of the sun.

The difference between a thermometer in sun and shade may I suppose be roughly defined as due to the excess of the heat rays which penetrate the former beyond those with which it can part. A bright, clear, glass bulb filled with mercury is evidently a mirror; it therefore reflects nearly all the heat rays which fall upon it, and therefore reads nearly the same in full blaze of the sun as in perfect shade. Hence it is useless as a measure of solar heat, and so long back as 1835 it was supplanted by a thermometer of which the bulb was blown in black glass. The next improvement was placing the thermometer inside a glass jacket, which was suggested about the year 1860 . The reason for this arrangement was very simple; the naked black bulb thermometer varied with every change of force in the wind, and no two instruments were comparable, because it was impossible to secure precisely similar currents over both thermometers. The glass shields have greatly diminished, but not removed, this source of error. The next improvement was to substitute a dull coating of black for the glassy surface which still acted as a partial reflector. Lastly, it was found that the unblackened stem of the thermometer reduced slightly the temperature of the bulb. Hence we arrive at the present form of instrument, a maximum thermometer, with its bulb and part of the stem dull blackened, enclosed in a glass shield or jacket. Most of them are at present made with nearly all the air exhausted from the shield (whence the term vacuum thermometers), but experiments are in progress with non-exhausted jackets, and that point must therefore be left open.

The difference between one of the earliest and one of the latest form of instruments will reach $60^{\circ}$ or $70^{\circ}$.

It was supposed that position did not affect these improved instruments, and so (for example) we have that at Greenwich lying on grass, that at Oxford "in a niche in the west front of the observatory about five feet from the ground." * Some experiments made by myself in 1867 showed that the temperatures on grass depended on the state of the grass, whether succulent or parched, and on its length. Hence it was evident that here again comparability was gone. After many experiments by the Rev. F. W. Stow and others, one of his suggestions was adopted, and the thermometer placed on a post at the same height ( $4 \mathrm{ft}$.) as everybody (except the Meteorological Committee) places their shade thermometers.

Having thus epitomised the progress of solar temperature observations, I proceed very briefly to the points already mentioned.

(r.) Explanation of the discrepancies.

\begin{tabular}{|c|c|c|c|c|c|}
\hline \multirow{2}{*}{$\begin{array}{l}\text { Observer : } \\
\text { Locality. } \\
\text { Mode of Obser. } \\
\text { vation }\end{array}$} & \multirow{2}{*}{$\left|\begin{array}{c}\text { Mr. Steward } \\
\text { Vac. }\end{array}\right|$} & \multirow{2}{*}{$\begin{array}{l}\text { Mr. Nunes } \\
\text { Chiselhurst } \\
\text { On Grass }\end{array}$} & \multirow{2}{*}{$\begin{array}{l}\text { Roy. Ob. } \\
\text { Greenwich } \\
\text { On Grass }\end{array}$} & \multicolumn{2}{|c|}{$\begin{array}{c}\text { Mr. Symons } \\
\text { Camden Square }\end{array}$} \\
\hline & & & & On Grass & $\begin{array}{l}4 \mathrm{ft} \text {. above } \\
\text { ground. }\end{array}$ \\
\hline & - deg. & deg. & deg. & deg. & deg: \\
\hline $\begin{array}{c}\text { August } 7 \cdot \text { : } \\
\quad 8 .\end{array}$ & $\begin{array}{l}113 \\
113\end{array}$ & $\begin{array}{l}I 48^{\circ} \mathrm{O} \\
\mp 47^{\circ} \mathrm{O}\end{array}$ & $\begin{array}{l}x 36 \% 9 \\
\times 30.5\end{array}$ & $\begin{array}{l}1274 \\
120^{\circ} 2\end{array}$ & $\begin{array}{l}1245 \\
\times 23.3\end{array}$ \\
\hline ," & I10 & & & 128.5 & $122 \%$ \\
\hline "10. & 112 & $148^{\circ}$ & $14^{\circ} 3$ & $124^{\circ} 5$ & I22. 3 \\
\hline$\Rightarrow$ Ir. & $x I 9$ & I5o & $x_{40}$ & $124: 3$ & \\
\hline$" 12$. & I 55 & $146^{\circ} 5$ & $x_{4} 6$ & & \\
\hline " 13. & 225 & $147^{\circ} \circ$ & 1510 & & \\
\hline Mean . . & $122 \% 4$ & $I_{4} 8: 4$ & $I_{4} I_{4}^{\prime}$ & 225.6 & ×227 \\
\hline
\end{tabular}

The instruments and their position at Chiselhurst,

* Radcliffe Met. Obs. r867, page 4. 
Greenwich, and Camden Square, are identical, but the Camden Square grass is by far the most "velvety," and hence partially its much lower temperature. Another and more powerful influence is smoke. Although neither photographers (eg. Mr. F. Bedford) nor artists, (e.g. Goodall, R.A., and Cousens, R.A.) deem this a smoky quarter, it is certainly more so than the Royal Observatory, which again is more so than Chiselhurst. Adding $5^{\circ}$ to my own readings for the succulence of the grass, we have the following mean values:-Camden $130^{\circ} 6$, Greenwich $141^{\circ} 5$, Chiselhurst $148^{\circ} 4$, whence there appears a regular increase with decrease of smoke. If Mr. Steward's instrument is in the heart of the City, the explanation is complete; but it may differ from the others in construction.

(2.) As this article has become longer than I intended, I will not enter into proof respecting the share in unravelling the inconsistencies of sun temperatures which is due to amateurs, but if required am ready to do so.

Lastly, it is solely to an amateur, the Rev. F. W. Stow, that we are indebted for establishing a small corps of observers in all parts of the British Isles, and some foreign countries, who use only thermometers compared in the sun, and mounted on posts so as to be free from terrestrial influences. This is what the private observers are doing, while the public observatories either ignore the subject in toto, or follow each its own traditions, and the meteorological societies print indiscriminately readings of thermometers on grass and on posts in jackets, and out of them.

G. J. SYMONS

\section{NOTES}

Tre arrangements connected with the Eclipse Expedition are making fair progress. The committee have telegraphed to America inviting Prof. Young to take part in the observations. Prof. Zöllner, of Leipzig, has also been asked to join the expedition. We are glad to know that the committee have received the most generous and valuable aid from the directors of the Peninsula and Oriental Steam Navigation Company, and of the British India Telegraph Company. This is as it should be.

IT is hoped that the spectroscope will be brought to bear on Encke's comet this autumn, as the positions will be about as favourable as it is possible for them to be for brightness and a dark sky ground. Mr. Hind informs us that he thought he glimpsed it in Mr. Bishop's refractor a few nights ago.

MR. HIND has communicated a very interesting letter to the Times on the solar eclipses of the next twenty years, which we hope shortly to reproduce with some additional facts.

WE have received from the Royal Society of Victoria a prospectus of the proposed Eclipse Expedition from that colony. It states that the Eclipse will be visible as a total Eclipse over a zone about eighty miles wide, passing across the peninsula of Cape York, the Gulf of Carpentaria, and Arnheim's Land to the north of Port Darwin. For the purpose of enabling scientific men in the Australian Colonies to observe the phenomenon, the Royal Society of Victoria proposes to charter a commodious and powerful steamer to carry a party to Cape Sidmouth, or such other point within the limits of totality as may be found most - suitable. It is not proposed that the party should be limited to members of the Royal Society, but that it shall be open to the public generally in that and the other colonies. To secure however hat no ineligible persons are admitted to the party, the names of all who are desirous to join must be submitted to the Committee appointed for the purpose by the Royal Society. Communications have already been made to the neighbouring Colonies, and many favourable answers have been received. Ii will be necessary for the expedition to start not later than the last week in November, and it will occupy about three weeks.
If possible, arrangements will be made to visit Feejee on the return voyage.

AMONGST the most recent additions to the Zoological Society's living collection, are two specimeas of the man-of-war-bird, or fregate-bird (Fregatc aquila), a well-known denizen of the seas of the Tropics, but one that has never previously reached this country alive. Five of these birds were taken from a breedingplace of this species in the Bay of Fonsecain, Central America, by Captain John M. Dow, C.M.Z.S., of the Panama Railway Company's service, and presented to the society, and two of them have reached the Regent's Park Gardens in excellent health and condition, and may now be seen in one of the compartments of the large Western Aviary. The Fregata is an aberrant form of the Pelecanoid type, remarkable for its great powers of flight, and with its structure modified accordingly.

THE new Aquarium at Brighton is now making rapid progress towards completion, some of the tanks being nearly ready to receive their contents. The building is on a very large scale, and will contain upwards of fifty large tanks. Unfortunately, however, no one with any practical knowledge of the working of a large aquarium seems to have been consulted as regards the plans, and there are consequently certain defects in the mode of construction which are likely to interfere with the efficiency of the establishment.

L'AbbE Moigno, the well-known editor of Les Mondes, proposes the estabishment of what he terms a "Salle du Progrès," in which an education shall be given which he considers the universities do not supply, - elementary, within the compass of any intelligent mind, and yet of the highest description as to quality. The main feature in the instruction thus given is to be the abundance of experiments and illustrations, whether in any branch of physical or natural science or in art. The illustrative - diagrams he proposes to be reproduced on glass by photography, so that they can be packed conveniently in a small box, and then magnified on a large screen by the magic lantern. Admission to the courses at the Salle du Progrès is to be at as low a price as possible, and for the working classes it is to be entirely gratuitous. Under the title of "Daily Bread". (le pain quotidien), L'Abbé Moigno proposes also the establishment of a daily journal of religion, politics, science, industry, and literature, intended to promote the regeneration of France by the cultivation of a higher standard than that acknowledged by the bulk of French literature. We wish the Abbé every success, and believe he may do much good by his efforts in these directions. How long are we to wait for scientific lectures for the people in London?

AN International Exhibition of Fruit, open to growers in this and other countries, is to be held in the grounds of the Royal Horticultural Society, at South Kensington, on October 4.

THE recent numbers of the Révue Scientifique contain an admirable summary of the most important papers read at the recent meeting of the British Association.

DR. MORTIMER, late head-master of the City of London School, whose death is just recorded, numbered among his pupils, according to the Pall Mall Gazette, several men very eminent in science, including Mr. Earnest Hart, and three senior wranglers, Mr. Aldis, Mr. Purkess, and the late Mr. Numa Hartog.

IN Mr. Robert Russell of Pilmuir, who died on the 3 rd inst., Scotland has lost one of her most painstaking and scientific meteorologists. A Scottish farmer by birth and training, his whole life was bound up in the agricultural profession. On his favourite study of meteorology, and other subjects connected with scientific agriculture, he was a frequent contributor to various journals, was the author of a work on the Climate and Agricul- 